\title{
Analysis of the Impact of International Monetary Fund Programs on Economic Performance of Kenya
}

\author{
Henry Kerich \\ Professor, School of Business, Strayer University, Washington DC Region, USA \\ E-mail: kerich75@gmail.com
}

Received: Jan. 2, 2016

Accepted: April 16, $2015 \quad$ Published: April 16, 2016

doi:10.5296/jmr.v8i2.9248

URL: http://dx.doi.org/10.5296/jmr.v8i2.9248

\begin{abstract}
Like most other developing countries, Kenya faces economic challenges as it tries to stabilize its balance of payments, reduce external debts and curb high unemployment rates. Structural adjustment programs (SAPs) are defined as economic programs mainly set for developing countries supported by the Bretton Woods institutions since the beginning of 1980s. As a result of prolonged balance of payments deficits, high unemployment rates and high debts, brought about by poor economic performance, the country has turned to International Monetary Fund for credit assistance. This research sought to examine if there was a relationship between structural adjustment programs and economic performance in Kenya. The results in this study revealed a significant correlation between IMF structural adjustment programs and economic performance in Kenya. The findings showed that the three dependent variables analyzed notably, balance of payments, debts, and unemployment showed a strong correlation with IMF structural adjustment programs.
\end{abstract}

Keywords: Economic performance, Structural adjustment programs, Kenya, conditionality, financial aid, IMF 


\section{Introduction}

International Monetary Fund (IMF) was established in 1945 to help in rebuilding Europe after the Second World War and to help in managing the international financial systems of member countries. Kenya is one of the developing countries that has been confronted with prolonged balance of payments deficits for decades and as a result, has turned to International Monetary Fund for its structural adjustment programs or credit needs. Structural adjustment programs (SAPs) are economic policies for developing nations sponsored by Bretton Woods institutions from 1980s (WHO, 2012). Structural adjustment programs comprise funding and conditionality provisions. Conditionality is defined as an economic condition imposed by the IMF on recipient countries upon disbursement of its funds (IMF, 2012).

International Monetary Fund and other donors have become highly worried that some of the financial aid meant for important programs ends up financing programs not earmarked for funding. Research findings shows that the problem of poor economic performance is faced by most developing countries despite the continuous inflow of IMF financial aid over the last few decades. For instance, Kenya highly depends on IMF financial aid, yet its economy still performs poorly and continues facing challenges of high foreign debts even after more than five decades of receiving IMF aid (Njeru, 2003).

The findings from this study revealed that IMF programs have not been effective in addressing economic problems in Kenya. It is therefore suggested that IMF should take a more supple approach and adapt its austerity measures to economic structure prevalent in Kenya.

\section{Problem Statement}

The fundamental role of the International Monetary Fund (IMF) is that of assisting member countries address their balance of payments problems and help in managing the international financial systems. However, in pursuit of these objectives of financial needs of its borrowers, IMF has come under intense criticism comprising lack of transparency, accountability, efficacy, conditionality, and moral hazard (Eke \& Kutan, 2008). The fund has received criticism for handling crises in a slow manner and those who oppose the workings of the IMF have argued that its policies and plans take a lot of time to negotiate and are often not effective (Bird, 2001). Corruption which is defined by IMF is an abuse of public office for personal benefit is also blamed for the poor economic performance in Kenya because it reduces the effectiveness of aid through the diversion and misuse of funds (IMF, 2012).

Like other developing countries, Kenya has been confronted with prolonged balance of payments deficits, unemployment and high debts for decades leading to poor economic performance. As a result of these tough economic conditions, leading to difficulty in obtaining financial assistance, Kenya has approached International Monetary Fund for credit needs through its structural adjustment programs. Structural adjustment programs (SAPs) are economic policies for developing nations sponsored by the Bretton Woods institutions from 1980s through loans advancement(WHO, 2012).

The problem that was examined in this study was the poor state of economic performance in 
Kenya despite the continuous inflow of external funding associated with IMF structural adjustment programs. Nouruddin and Simmons (2006) presented facts showing that structural adjustments has led to a decrease in education and health care expenditure leading to poor economic performance in developing countries.

\section{Purpose of the Study}

This study sought to close the present literature gap on the relationship between International Monetary Fund programs and economic performance in Kenya. Economic performance can be defined as economic growth, labor productivity growth, and consumer welfare (McKinsey Global Institute, 2001). Though Kenya has been receiving financial assistance from IMF for decades in the form of structural adjustment programs, the economic performance has not improved much and cases of fund diversion in public service still exists.

Structural adjustment programs comprising funding and conditionality provisions were the points of interest in this study. While several studies have been conducted on the impacts of structural adjustment programs in different developing countries, none of these studies has specifically addressed the relationship between IMF programs and economic performance in Kenya but have rather addressed specific factors. For example, Parsitau (2008) conducted a study that examined the impact of structural adjustment programs on the health of women in Kenya. In this study, Parsitau (2008) findings argued that the austerity measures introduced by SAPs led to a decline in the health of most women in Kenya.

\section{Literature Review}

Research on effectiveness of international financing on savings and investment in low income nations raises issues on the proper use of aid on their intended programs (White, 1992). International Monetary Fund and other donors have become highly worried that some of the financial aid meant for important programs ends up financing programs not earmarked for funding. Despite the major responsibilities that the IMF and other international institutions play in providing financial aid to developing countries, it is perplexing to realize that a high degree of debt, rising unemployment, abject poverty, corruption and general poor economic performance still persist in these countries. Poor economic performance in Kenya has been attributed to IMF conditionalities and corruption. Previous studies showed that corruption reduces the effectiveness of aid through the diversion and misuse of funds (IMF, 2012).

\section{IMF Organization}

\section{Management and Staff}

International Monetary Fund is headed by a managing director acting as the head of staff as well as executive board head. The director is deputized by four deputy managing directors. This group of executives manages the staff and keeps top relations with member countries, non-public institutions, think tanks, and other organizations (IMF, 2013). Presently, IMF has around 2,400 staff, most of whom are economists. The majority of them are assigned at the IMF headquarters in Washington, DC and just a small number work in member nations throughout the world in small IMF overseas offices or as resident representatives. With its 
almost global presence, the IMF attempts to employ staffs who from diverse backgroundand widely based geographically. The IMF has nine key departments that carry out its policy, analysis, and technical work and administration of its monetary resources (IMF, 2012). Resident representative who are stationed in different member countries acts as liaison officers for the institution. Following are the chief responsibilities performed by the resident representatives and can be classified into three main groups:

1. Monitoring developments and providing information and analysis to headquarters

2. Providing assistance to, and communicating with, the country authorities

3. Engaging in outreach activities, including contacts with the media

\section{Borrowing Arrangement}

At times IMF readies itself for potential unforeseen financial crisis by borrowing funds from a number of member countries and some institutions. Presently IMF has two established multilateral borrowing preparations and one bilateral borrowing agreement. These credit preparations involving a set of member countries and the fund can offer additional funds of up to approximately $\$ 26$ billion under the General Arrangements and approximately $\$ 565$ billion under the New Arrangements to the IMF to deal with a shortfall or handle a special circumstances that poses a danger to the stability of the international financial system.

\section{Gold}

To be guaranteed of financial stability and meet unforeseen emergencies, IMF holds a fairly huge reserve of gold amongst its resources. The IMF has nearly 90.5 million ounces of gold at the chosen depositories. The fund's entire gold holdings are worth approximately $\$ 4.9$ billion in terms of chronological cost. The IMF's assets total about $\$ 160$ billion as determined by end-February 2012 market prices (IMF, 2012).

\section{IMF Conditionality: Effects and Criticism}

Conditionality is a practice whereby IMF and World Bank attach the granting of their loans to policy restructuring in the borrowing countries. This practice was first introduced by the IMF in the 1980s. Under this process, IMF generally demands some conditions to be met aimed at reducing the country's fiscal deficits. However, from 1980s, the IMF started attaching conditions to advancement of its loans (Koeberle, 2003). The significance of these austerity measures constantly rose over time with the amount of conditions gradually increasing (Dreher, 2009). This addition of austerity measures has faced great criticisms as has the model and the particular content of IMF austerity measures.

From the time conditionality was started in 1980 s, it has generated intense debate especially from the low-income countries that happen to be the most beneficiaries of the loan packages from the IMF. In fact for several years, advocates of this concept argue that unless the recipient nations adopt economic liberalization policies, foreign loans planned to support development would just promote and sustain ineffective regimes (World Bank, 2012). Attaching aid to policy restructuring was therefore projected to make the loans more useful 
and help improve standard of living in recipient nations. Additionally, those who are criticizing conditionality argue, nonetheless, that the economy-centered policies attached to assistance might encourage progress though at the cost of majority poor in the borrowing countries (Montinola, 2010).

A number of scholars have asserted that IMF policies concentrate too much on cutting cumulative demand thereby endangering growth (Allen, 1984). IMF has also been accused of ignoring the needs of the poor and for not taking the social consequences of its conditions into account (Dreher, 2009). Austerity measures leads to reduction in the already poor living conditions of the people. Trade liberalization destroys local manufacturing and increase unemployment. Economic liberalization opens up less developed nations to investments from international companies but the gains of these investments would accumulate only to the multi nationals and a small cluster of elites in loan recipient nations (Montinola, 2010).

From another perspective, proponents of the IMF have responded to the critics saying that their approach comes directly from the free market economy. Additionally they contend that IMF is needed to conduct Washington's consensus, and the nations with economic problems will soon get out of them (Donalgic \& Kozaric, 2010). Researchers have suggested that IMF structural adjustment programs have been successful and tend to show that there has been minimal level of economic growth in developing nations who are utilizing the IMF policies (Killick, 1995; Serin \& Arican, 2002). The theories that have been advanced by the previous studies state that the economic situations in the developing nations would have been worse were it not for the structural adjustment programs rescue. However, these theories have been rejected by the dependency and world systems theories who argue that structural adjustment programs worsen the situations in developing countries by giving advanced countries more power and control over the developing nations.

\section{Utilization of IMF Funding}

Funding is the advancement of finance by way of loan packages by the IMF to the borrowing member countries upon the fulfillment of economic measures known as conditionality provisions (IMF, 2012). In most organizations, the responsibility of resource allocation lies in the hands of management. For the successful discharge of this responsibility, management needs to have all the resource information that helps in attaining the organizational objectives (Mason \& Swanson, 1979). The allocation of IMF resources which is vested in the hands of IMF Staff is determined primarily by their mandate for surveillance and thus, the relative systemic importance of individual countries. In developing countries, there has been failure by the government to allocate the IMF resources fairly and prudently. Government failure refers to the failure to distribute resources efficiently, to distribute them in a well targeted manner, and to stabilize the economy in the period of stagflation (Tanzi\&Schuknecht, 2000).

The allocation of foreign aid should be need-based and equitably distributed but instead, allocation of funds has often been done on the basis of ethnicity and political patronage in most developing countries. Corruption can lead to bad and damaging effects to the resource allocation since it often leads to misappropriation of funds. Two recent studies by Mauro 
(1997) and Tanzi and Davoodi (1997) have tried to demonstrate statistically the degree to which corruption alters the allocation of spending.

Corruption is defined as an unlawful compensation to a civic official to gain an advantage that may or may not be merited or, the misuse of civic offices for personal gains. Such cases directly affect the general performance of the economy. Kenya is not exempted from the patterns of corruption and diversion of aid projects, and donors have frequently expressed reservations over the extent of corruption in aid (Wrong, 2009). For instance there are many documents detailing the efforts by politicians to use aid for political purposes in Kenya. Cohen (1995) noted that ethnicity and ethnic demands are prominent issues in formulating and developing aid packages and projects.

Similarly, Otieno (2006) contended that one of the biggest corruption scandals engulfing Kenya is the outrage at the depth of official corruption involving government ministers and top civil servants. This has continued despite the fact that finance ministry has some tools at its disposal to reduce rent-seeking behaviors (corruption) of the government officials. These tools comprise internal controls in the ministries and measures for equitable distribution of resources.

The existence of aid-fungibility which is a process whereby government adjusts existing budget allocations in reaction to the allocation and diversion of aid to a particular sector has been documented by Njeru (2003). Additionally, Njeru (2003) stated that, typically only about $80 \%$ of the aid funds are spent on development. In a recent audit of a large World Bank HIV project in Kenya, auditors noted that legislators were personally involved in the disbursement of funds and that project committees were frequently packed with loyal supporters, allowing politically connected grant applicants to obtain significant advantages by virtue of their connection to MPs (World Bank, 2012).

Corruption generally increases public spending and distorts its allocation. It increases public spending: by encouraging needless or unproductive spending; by leading to the overpayment for some services or goods that the state purchases; by making payments to persons not entitled to these payments. According to Moyo (2010), foreign aid may actually be promoting corruption all over Africa because of ethnically based motivations. Additionally, she argues that aid funds makes African politics a high-stakes playing arena and thus contributes to the corruption it seeks to end. Corruption in public sectors becomes a huge problem in the economy because it reduces the effectiveness of aid through the diversion and misuse of funds (IMF, 2012). Consequently, such cases directly affect the general performance of the economy.

\section{Research Methodology}

This is a correlation study seeking to examine linear relationship between structural adjustment programs and economic performance in Kenya. Random sampling was used in the study. Random sampling provides members of the population an equal chance of being selected for inclusion in the sample (Vogt, 2007). A period of 2005-2008 was chosen for this study because of the diversification that took place in developing countries from the year 2000 (Papageorgiou 
\& Spatafora, 2012) and the completeness of data available for those years.

\section{Analysis and Results}

For the purpose of examining the relationship of variables in this study, the researcher used Pearson correlation analysis through the application of SPSS software. This technique measures the relation between two variables without distinctions between the independent and dependent variable (Mertler, \&Vannatta, 2002). The yearly account changes in the structural adjustment programs was used as an independent variable as mentioned in all the three hypotheses. During the analysis, Pearson correlation coefficient $r$ was compared with the critical r-value .389. For cases in which Pearson correlation $r$ was greater than the critical $\mathrm{r}$ rate, the Pearson value was significant and in cases where the $\mathrm{r}$ rate was less than .389 , Pearson correlation was not significant.

Significant level was set at .01 and .05. Null hypothesis was rejected whenever the Pearson correlation value was greater than the critical value. And where the Pearson correlation value was less than the critical value, null hypothesis (H0) was accepted. It was also presumed that a level of significance below a particular level might have happened by chance. Therefore any $\mathrm{r}$ value below .389 was taken to have happened by chance whereas a value above .389 indicated a strong relationship between the variables. During this period of study (2005-2008), the annual accounts of structural adjustment programs were expected to rise. On the other hand, unemployment rates, debt levels and balance of payments deficit were expected to fall. The purpose was to find interrelationship, if any, between structural adjustment programs and the above three dependent variables so as to understand whether structural adjustment programs have negatively or positively contributed to the economic performance of Kenya.

\section{Hypothesis One Results}

Research question 1 set the stage for the first analysis asking the question: what is the relationship between structural adjustment programs as measured by the year-end totals and balance of payments as measured by the GDP? Hypothesis one posited that there was a significant relationship between structural adjustment programs and balance of payments. 
Table 1. Association Between IMF Programs and Balance of Payments in Kenya

\begin{tabular}{|c|c|c|c|}
\hline & & $\begin{array}{l}\text { Structural Adjustment } \\
\text { Programs }\end{array}$ & Balance of Payments \\
\hline $\begin{array}{l}\text { Structural } \\
\text { adjustment } \\
\text { Programs }\end{array}$ & $\begin{array}{c}\text { Correlation } \\
\text { Coefficient } \\
\text { Sig. } \\
\text { (2-tailed) } \\
\mathrm{N}\end{array}$ & $\begin{array}{l}1 \\
4\end{array}$ & $\begin{array}{c}-.906 \\
.904 \\
4\end{array}$ \\
\hline $\begin{array}{l}\text { Balance of } \\
\text { Payments }\end{array}$ & $\begin{array}{c}\text { Correlation } \\
\text { Coefficient } \\
\text { Sig. } \\
\text { (2-tailed) } \\
\mathrm{N}\end{array}$ & $\begin{array}{c}-.906 \\
.904 \\
4 \\
4\end{array}$ & 1 \\
\hline
\end{tabular}

The result in Table 1 shows that there was a significant negative association between IMF programs and balance of payment in Kenya whereby an increase in structural adjustment programs led to decrease in balance of payments. Pearson $r$ value for this relationship was -.906 and significant at .01 and .05 . As a result, null hypothesis was rejected because this value was greater than critical r-value .389 .

\section{Hypothesis Two Results}

Research question two asked: What is the relationship between structural adjustment programs as measured by the year-end totals and debt levels as measured by the year-end totals? Hypothesis two posited that there was a significant relationship between IMF programs and debt levels.

Table 2. Relationship between structural adjustment programs and debt level in Kenya

\begin{tabular}{|ll|c|c|}
\hline & & $\begin{array}{l}\text { Structural adjustment } \\
\text { Programs }\end{array}$ & Debts \\
\hline Structural & Correlation & 1 & .620 \\
Adjustme & Coefficient \\
nt & Sig. (2-tailed) & & .380 \\
Programs & $\mathrm{N}$ & 4 & 4 \\
\hline Debts Correlation & Coefficient & .620 & 1 \\
& Sig. (2-tailed) & .380 & \\
& $\mathrm{~N}$ & 4 & 4 \\
\hline
\end{tabular}


The existence of a statistically significant relationship between IMF structural adjustment programs and the rising debt level in Kenya helped to affirm the hypothesis that as the IMF programs rose, the debt level rose as well. Pearson correlation $r$ value of .620 shows a significant positive relationship between the two variables and since this value is higher than the critical value of .389 and significant at both .01 and .05 levels, null hypothesis was rejected.

\section{Hypothesis Three}

Hypothesis three posited that there was a significant relationship between structural adjustment programs and unemployment.

Table 3. Association of structural adjustment programs and unemployment in Kenya

\begin{tabular}{|lr|c|c|}
\hline & \multicolumn{2}{|l|}{ Structural Adjustment } & \\
& & Programs & Unemployment \\
\hline Structural & Correlation Coefficient & 1 & .577 \\
Adjustment & Sig. (2-tailed) & & .423 \\
Programs & $\mathrm{N}$ & 4 & 4 \\
\hline Unemploy & Correlation Coefficient & .577 & 1 \\
ment & Sig. (2-tailed) & .423 & 4 \\
\hline
\end{tabular}

The result of this analysis shows that there was a positive association between structural adjustment programs and unemployment rates in Kenya such that as structural adjustment programs increased, the unemployment rates increased as well. The Pearson correlation $r$ value of .577 was greater than the critical value of .389 and significant at both .01 and .05 and therefore the null hypothesis (HO) was rejected.

\section{Recommendations}

The austerity measures imposed by way of conditions along with rent seeking behaviors (corruption) by government officials in Kenya has resulted in hard economic conditions reflected in low standard of living and increase in poverty levels. IMF conditionalities can possibly harm the countries' economies instead of improving them by changing financial crisis into a rip-roaring economic recession (Bird, 2001). International Monetary Fund should lessen the attachment of conditionalities to its funding. In as much as conditions ensure accountability and prudent responsibility, it should not be in the way of development.

Additionally, past empirical studies have shown and supported the assertion that IMF uses one size fits all approach in its dealings and transaction with member countries regardless of their specific conditions and dynamics. This assertion is supported by a study conducted by Marshall (2009) which analyzed the task of the IMF in supporting particular tax policies in 18 African nations using official information to generate an exceptional data set summarizing Fund recommendation. The findings of this study unfortunately showed that the evidence presented broadly supported this hypothesis for key areas of tax policy. It is the 
recommendation of this researcher that IMF has to stop applying a blanket policy on their transactions with its member countries but rather consider each country particular situation.

Finally, it is further suggested that primary data through qualitative interview methods be utilized for further research on this topic. This quantitative study solely used secondary data which consisted of data that had already been collected by other organizations for different purposes. Therefore the original objective for the collection of this data differs from the objective of the present study. Validity is a great concern in any research. The use of primary data can help advance the validity of research. It is also recommended that the Kenyan government should make concerted effort in fighting corruption and impunity which is associated with diversion and misuse of funds.

\section{Conclusion}

The purpose of this research was to examine the relationship between IMF programs and economic performance in Kenya. This analysis was made possible through the use of Pearson correlation coefficient analysis. As a result, the existing literature gap on the relationship between IMF structural adjustment programs and economic performance in Kenya has been narrowed. In addition, the results of this research could be of great help in addressing the overall economic recovery and stabilization policies in Kenya.

Overall, the above results indicate a significant correlation between IMF structural adjustment programs and economic performance in Kenya. For example, the results on the relationship between structural adjustment programs and balance of payments indicate a significant negative relationship. This relationship means that as IMF continued to advance financial loans to Kenya, the balance of payments deficit continued to rise. The results also revealed that the debt level in Kenya has a strong positive relationship with structural adjustment programs in the period of study. This finding shows that as IMF continues to advance its loans to Kenya, debt level continues to rise as well. Similarly, the findings from the relationship between structural adjustment programs and unemployment indicated a strong relationship.

Lastly, the researcher believes that the results from this analysis will address the existing literature gap on the relationship between IMF programs and economic performance in Kenya. Additionally, these findings will stimulate further discussion and contribute to general approaches and thus improve the existing economic conditions in Kenya.

\section{References}

Bird, G. (2001). IMF programs: do they work? Can they be made to work better? World Development, 29, 1849-1865. http://dx.doi.org/10.1016/S0305-750X(01)00077-8

Donlagic, D., \& Kozaric, A. (2010).Justification of criticism of the international financial institutions. Economic Annals, 55(186), 115-132.

Dreher, A. (2009). IMF conditionality: Theory and evidence. Public Choice, 141(1/2), 233-267. http://dx.doi.org/10.1007/s11127-009-9486-z 
Eke, B. \& Kutan, A. (2008). Are international monetary fund effective? Eastern European Economics, 47(1), 5-28. Retrieved from ProQuest

International Monetary Fund (2003). IMF external debt statistics. Guide for compilers and users. Retrieved from imf.org

International Monetary Fund (2012).Balance of payments and international investment position compilation Guide. Retrieved from www.imf.org

Kelly, M. R. (1982). Fiscal adjustment and fund-supported programs, staff papers, International Monetary Fund (Washington), 29, 561-602. Retrieved from www.imf.org

Koeberle, S. G. (2003). Should policy-based lending still involve conditionality? World Bank Research Observer, 18(2), 249-273. http://dx.doi.org/10.1093/wbro/lkg009

Mauro, P. (1997). The effects of corruption on growth, investment and public expenditure: A cross country analysis, in corruption and the global economy. Washington: Institute for Economics

McKinsey Global Institute. (2001). U.S. productivity growth 1995-2000: Understanding the contribution of information technology relative to other factors. Retrieved from www. McKinsey.com

Mertler, C. A., \& Vannatta, R. A. (2002).Advanced and multivariate statistical methods (2 ${ }^{\text {nd }}$ ed.). Los Angeles, CA: Pyrczak Publishing.

Montinola, G. R. (2010). When does aid conditionality work? Studies in Comparative International Development, 45(3), 358-382. http://dx.doi.org/10.1007/s12116-010-9068-6

Moyo, D. (2009). Dead Aid: Why aid is not working and how there is another way for Africa. London: Allen Lane.

Njeru, J. (2003). The impact of foreign aid on public expenditure: The case of Kenya, AERC research paper 135. African Economic Research Consortium. Retrieved from www.aercafrica.org

Nouruddin, I., \& Simmons, J. (2006). The politics of hard choices: IMF programs and government spending. International Organization, 60, 1001-1033. Retrieved from ProQuest. http://dx.doi.org/10.1017/s0020818306060334

Otieno, R. (2006). The impact of tax and corruption on livelihood in Kenya: Views ofyoung .The Manchester Metropolitan University. Retrieved from www. Visar.csustan.edu

Papageorgiou, C., \& Spatafora, N. (2012). Economic diversification in low-income countries: stylized facts and macroeconomic implications. Retrieved from imf.org

Parsitau, D. S. (2008).The impact of structural adjustment programs (SAPs) on women's health in Kenya. Governing Health Systems in Africa, 191-199. Retrieved from codesria.org

Sihanya, B. (2008). The Impact of IMF policies on education, health and women's rights in Kenya, action aid Kenya, Nairobi. Retrieved from actionaidusa.org 


\section{Macrothink}

Journal of Management Research

ISSN 1941-899X 2016, Vol. 8, No. 2

Tanzi, V., \& Davoodi, H. (1997).Corruption, Public Investment and Growth.IMF Working Paper 97/139. International Monetary Fund. Washington, D.C. Retrieved from imf.org. http://dx.doi.org/10.5089/9781451929515.001

Vaubel, R. (1996). Bureaucracy at the IMF and the World Bank: A comparison of the evidence. The World Economy, 195-210. http://dx.doi.org/10.1111/j.1467-9701.1996.tb00672.x

White, H. (1992). The macroeconomic impact of development aid: A critical survey. Journal of Development Studies, 28, 163-240. http://dx.doi.org/10.1080/00220389208422230

World Bank.(2012). Foreign direct investment, net inflows (BoP, current US\$). Retrieved from http://data.worldbank.org

World Development Indicators. (2012). Primary data documentation. World Bank Group, World Bank, Washington, DC. Retrieved from www.Worldbank.org

World Health Organization. (2012). Structural adjustment programs: Trade, foreign policy diplomacy and health. Retrieved from http://www.who.int/trade/ 